\title{
CHAPTER THREE
}

\section{MARTYRS OF “OUR” FAITH: IDENTITY AND THE CULT OF SAINTS IN POST-HUSSITE BOHEMIA}

\section{KATEŘINA HORNÍČKOVÁ}

When in 1415 the rector of Prague University and religious reformer Jan Hus was burnt at stake in Constanz, Bohemia's attempt to religious reform evolved in the Hussite wars. ${ }^{1}$ Their settlement in 1436 at the Council of Basel legalised the existence of the Hussite non-Catholic enclave within Western Christianity. The Basel Accord, sealed in 1436, created the

1 For the Hussite movement, see František Šmahel, Hussitische Revolution, vol. 1-3, Monumenta Germaniae Historica Schriften 43 (Hannover: Hahnsche Buchhandlung, 2002), and Howard Kaminsky, A History of the Hussite Revolution (Berkeley \& Los Angeles: University of California Press, 1967). This article has been prepared for publication in 2013, meanwhile a number of new books on Jan Hus and the Hussites appeared, which could not be fully considered here, among others Thomas A. Fudge, The Memory and Motivation of Jan Hus, Medieval Priest and Martyr (Turnhout: Brepols, 2013) and lately idem., Jan Hus between Time and Eternity: Reconsidering a Medieval Heretic (Lanham MD: Lexington Books, 2016).

The present study was revised for publication in the framework of a research project financed by the Special Research Programme (SFB) 42 Visions of Community, Project 4206 Social and Cultural Communities in High and Late Medieval Central Europe (PI: Ch. Lutter) funded by the Austrian Science Fund (FWF). 
legal framework for the existence of the semi-independent Bohemian Utraquist Church (sub utraque specie - distribution of lay chalice). The Bohemian Utraquist (Calixtine) church, as the Hussite offspring came to be called later, and its splintoffs, was viewed with a great suspicion from outside Bohemia as the Bohemian heretical church.

In the negotiations leading to the Basel Treaty of 1436, the Catholic party accused the Czech Hussites, among many other things, of their hostile approach to the cult of saints. Especially, the Catholic officials reproached them for denying the Virgin Mary and saints any merits in human salvation, and for destroying images and relics of saints. ${ }^{2}$ This view shaped later perspectives on the Hussite approach to the saints, and was often applied broadly to the whole reform movement. This simplistic view, formulated by the opponents of the

${ }^{2}$ A comprehensive work on Hussite iconoclasm is still missing. For orientation see Horst Bredekamp, Kunst als Medium sozialer Konflikte. Bilderkämpfe von der Spätantike bis zur Hussitenrevolution (Frankfurt am Main: Suhrkamp, 1975). Milena Bartlová, “Understanding Hussite Iconoclasm,” Bohemian Reformation and Religious Practice 7 (Prague: Filosofia, 2009), 115-126, eadem, Hussite Iconoclasm, in From Hus to Luther. Visual Culture in the Bohemian Reformation, ed. Kateřina Horníčková, and Michal Šroněk (Turnhout: Brepols, 2016), 57-70. (An earlier version of Bartlová's article appeared as Milena Bartlová, "Husitské obrazoborectví,” in Uměni české reformace (1380-1620), ed. Kateřina Horníčková and Michal Šroněk (Prague: Academia, 2010), 6370. I am using catalogue entries by various authors from this book, cited in the following as Uméní české reformace). 
Bohemian Reformation, infiltrated later scholarly discourse it was repeated e.g. by Marxist historians of the Hussites, who inclined to ignore the religious aspect of the movement and scorned its conciliatory outcomes as too compromising and appeasing the Catholics. Until recently it was maintained also by historians of the Reformation, who uncritically accepted the arguments of polemical treatises and often failed to confront the theological reading with relevant visual and material sources. The modern Catholic historians, who went beyond Counter-Reformation silence about the Bohemian Reformation, identified largely the Utraquists' acceptance of saints with the Catholic cultic manner, ignoring their different attitude to the cult, undercurrent critique, as well as the movement's diverging opinions and internal development. In reality, the view of saints' merits and intervention in Hussite and Utraquist teaching varied among different fractions of the religious movement, from refusal by the radicals to acceptance by conservatives.

This text approaches the cult of saints in Utraquism from two angles: from the point of the theological thought and normative codes, and from the point of monuments produced for religious practice. The first part sketches the development of saints' theology in Utraquism and its Catholic and Hussite 
inspiration, and explores nuances in teaching between different groups. ${ }^{3}$ Then, visual and liturgical documents are brought together to demonstrate how religious practice was influenced by theology and religious policy, and how Utraquist denominational identity was stabilised and communicated through commemoration of saints. ${ }^{4}$ It unmasks

${ }^{3}$ In spite of an evident surge of interest in cultural memory and the cult of Hussite saints in the past few years, comprehensive work on the topic is still lacking. The research on the cult of saints in the Bohemian Reformation focused either: 1. on the cult of Hus (including literary and liturgical commemoration), or 2. on critical arguments against it. For the first approach, see Achim Thomas Hack, "Heiligenkult im frühen Hussitismus. Eine Skizze," in Patriotische Heilige. Beiträge zur Konstruktionreligöser und politischer Identitäten in der Vormoderne, ed. Dieter R. Bauer, Klaus Herbers, and Gabriella Signori, Beiträge zur Hagiographie 5 (Stuttgart: Franz Steiner 2007), 123-156 (with overview of literature regarding the first approach) or Thomas Fudge, Jan Hus. Religious Reform and Social Revolution in Bohemia (London - New York: I.B. Tauris, 2010). The second approach is demonstrated by Ota Halama, Otázka svatých v české reformaci (Brno: L. Marek 2002), where the author analyses a selection of written sources illuminating some of the critical points, without mentioning Hus' cult. Art history, and liturgy contributed considerably to new perspective on the cult of Hus (e.g. Jan Royt, "Ikonografie Mistra Jana Husa v 15. až 18. století," in Hus na prelomu tisíciletí, ed. Miloš Drda, František J. Holeček, and Zdeněk Vybíral, Husitský Tábor Supplementum (Tábor: Husitské muzeum v Táboře 2001), 405-452, and other works cited in this article).

${ }^{4}$ On the integrative power of saints in the formation of a community, see

Peter Brown, The Cult of the Saints. Its Rise and Function in Latin

Christianity (London: SCM Press, 1981), 104-5. For denominational memorial culture in this sense, see Martin Sallmann, "Reformatoren und Heilige als Brennpunkte konfessioneller Gedächtniskulturen: Martin Luther, Karl Borromäus und Johannes Calvin im Vergleich,”

Schweizerische Zeitschrift für Religions- und Kulturgeschichte 103 (2009), 99-116. On demonstrating religious identity through monuments and 
Utraquist preference for particular saints, as well as the different meanings which (groups of) saints represented for Utraquist communities. Did the cult of saints function as an expression of a Utraquist religious and political identity in the reality of the Bohemian religious divide? ${ }^{5}$

The Hussite and Catholic foundations

With the influence of Matthew of Janov, and wyclifite ideas on the Hussite theologians Jacobellus of Stríbro and Nicolas of Dresden, the radical Hussite party's view of the contemporary Catholic cultic practices of veneration of saints'

cultural memory, Kateřina Horníčková, "Beyond the Chalice. Monuments manifesting Utraquist religious Identity in the Bohemian urban Context in the fifteenth and early sixteenth Centuries," European Review of History: Revue europeenne d'histoire 20.1 (2013), 137-152.

${ }^{5}$ For group identity Otto Gerhard Oexle and Andrea von Hülsen-Esch, eds., Die Repräsentation der Gruppen. Texte - Bilder - Objekte

(Göttingen: Vandenhoeck and Ruprecht, 1998), where esp. Klaus Krüger, "Selbstdarstellung im Konflikt. Zur Repräsentation der Bettelorden im Medium der Kunst," in ibidem, 127-186. For using a patron saint figur efor uniting religious community see Pamela Sheingorn, "'Illustris patriarcha Joseph': Jean Gerson, Representations of Saint Joseph, and Imagining Community among Churchmen in the Fifteenth Century," in Visions of Community in pre-Modern World, ed. Nicholas Howe (Notre Dame: University of Notre dame Press 2002), 91. 
relics and images was largely negative. ${ }^{6}$ The Prague University articles against "wyclifites" of 1412 and the following synod of 1413 urged fellow priests and masters to defend the cult of saints' relics, refuted by the more radical colleagues. ${ }^{7}$ The accusations against Jeroným of Prague at the Council of Constance were blaming him of a similar negative view. Based on Matthew of Janov's ideas, Jacobellus' texts of 1415 and 1417 argue against veneration of relics and images, seeing them as unnecessary additions, a fallacy or priestly greed that diverts faithful from the Corpus Christi. ${ }^{8}$ Nicolaus of Dresden in his treatise on saints and sermons goes as far as to contest any role of saints in human salvation, ${ }^{9}$ thus theoretically preparing the way for the Hussite iconoclasm.

In reaction, conservative opinions were gaining ground among more conservative part of the University masters. A

\footnotetext{
${ }^{6}$ Halama, Otázka svatých, 12-17. Jana Nechutová, "Prameny předhusitské a husitské ikonofobie,” Husitský Tábor 8 (1985): 29-37. Jana Nechutová, “Traktát Mikuláše z Drážd'an 'De Imaginibus' a jeho vztah k Matěji z Janova,” Sbornik praci filosofické fakulty Brněnské university E 9.13 (1964), 149-161 (demonstrating Bohemian rather than wyclifite origin of the critique). Kristína Sedláčková, "Jakoubek ze Stř́ibra a tzv. Týnské kázání z 31. ledna 1417. Názory předhusitských a husitských 'reformátorů' na obrazy," Opuscula historiae artium. Studia minora facultatis philosophicae universitatis Brunensis F 48 (2004), 7-43.

${ }^{7}$ Halama, Otázka svatých, 16.

${ }^{8}$ Halama, Otázka svatých, 17.

${ }^{9}$ Jana Nechutová, ed. Nicolaus von Dresden. Querite primum regnum dei, Opera Universitatis Purkynianae Brunensis. Facultas philosophica 119 (Brno: Univerzita Jana Evangelisty Purkyně, 1967).
} 
conservative-Hussite pamphlet (1417-1419) defended the Catholic cultic practice, illustrating the sharp rift between ideas of the Hussite radicals and the conservatives; the latter agreed not only to the unrestricted use of relics and images in the churches, but contrary to the demands of the radicals, they did not forbid kneeling and praying in front of them. ${ }^{10}$ The situation culminated in the Hussite iconoclasm soon after 1415 and in the first years of the Hussite wars (1419-1421/4), that branded the Hussites as fervent iconoclasts and provoked angry reactions from the Catholic side. Yet even at this stage the Hussites were not unanimous; different views on the form of the cult existed, for example, between neighbouring urban communities, as it is shown by different reactions by leaders of Prague New and Old Towns to the Taborite call for destruction of churches, altarpieces and images. ${ }^{11}$

Over three decades of the controversy, a broad spectrum of opinions concerning the role of saints in the Christian religion resulted in two distinct traditions that shaped the Utraquist perspective on saints, one regarding the practice of the cult

${ }^{10}$ Blanka Zilynská, Husitské synody v Čechách 1418-1440. Př́spěvek $k$ úloze univerzitnich mistrů v husitské církvi a revoluci (Prague: Univerzita Karlova, 1985), 38. Purpose and dating of the so-called Text B related possibly to the convocation on St. Wenceslas Day in 1418 is still debated. Cf. also polemics of Jan of Jesenice and Jacobellus of Stříbro, see Halama, Otázka svatých, 21-22.

${ }^{11}$ Halama, Otázka svatých, 29-30. 
and the second regarding the capacity of saints to intervene on behalf of the faithful. ${ }^{12}$ As were the garments and ornaments in the mass, the use of images and relics of saints was often regarded by the radicals as human additions (traditiones hominum $^{13}$ ), unnecessary or right away damaging exercises without any biblical support. In spite of theological disputes about the intervention and merits of saints, a positive role of saints was acknowledged by the majority of the movement, including the radicals - the problem was that different parties conceded them different portions of merits and competence. The two problematic perspectives needed to be reconciled with another Hussite novelty, the cultic commemoration of Jan Hus and Jeroným of Prague that may have also eventually helped to establish a compromise for the Hussite view on saints.

The situation resulted in polemical exchanges of opinionsover almost three decades between the radicals (first the Taborites, later the Unity of Brethren), the conservatives (led by a group of Prague University Masters), the emerging

12 The two core questions are rooted in late medieval theological definitions of sanctity, for Bohemia applied by Jaroslav Uhlír, Ceská reformace: Svatost a/nebo zbožnost, http://digit.nkp.cz/mns/uhlir_ceska_reformace.htm, consulted 2.1.2014.

${ }^{13}$ Amedeo Molnár, Jan Želivský. Dochovaná kázání z roku 1419, vol. 1, Od neděle velikonoční do páté neděle po sv. Trojici (Prague: Nakladatelství Československé akademie věd, 1953), 16. 
moderate party led by Jan Rokycana, and the Catholic party, leaving a series of interesting argumentative and normative texts, such as treatises, synodal orders, sermons, letters, articles, and songs dealing with the cult of saints. ${ }^{14}$ Iconophobic and anti-cult standpoints were expressed in a number of them, but the opposite arguments favouring saints prevailed. The split on the question of religious practices involving saints continued well into the 1440s, and it is still echoed in texts by more radical writers in the last third of the fifteenth century.

Imitating the ecclesia primitiva

At the Prague Hussite synod of 1421, the authority of the Roman church was challenged by stating the authority of the Bible and the early apostolic church, ${ }^{15}$ regarded as an ideal Christian society by the Hussites. Early Christian martyrs were seen as witnesses and perpetuators of an ideal community that practiced a Christian cult in a simple fashion

\footnotetext{
${ }^{14}$ Halama, Otázka svatých, 15-64. Zilynská, Husitské synody v Čechách.

${ }^{15}$ Zdeněk Nejedlý, Prameny k synodám strany pražské a táborské v létech 1441-44 (Prague: Nakladatelství Královské české společnosti nauk, 1900), 6-7, http://www.archive.org/details/pramenyksynodam00nejegoog, consulted 2.1.2014.
} 
and, thus, as an appropriate model for the life of the faithful and their religious practices. This view persisted in the Hussite documents into the 1430s, and it lingered on among more radical theologians, but gradually, the tone of the leading Hussite party documents turned more moderate. The articles of agreement between the Prague Hussites and the priests of the radical Orphans (Sirotci) in early January 1432 (forming the core of the emerging Utraquism) gave the Apostels and the primitive church overall authority in questions of cult, drawing on a division between human additions to cult and divine inspiration: all Christian rules should be kept

... according to the understanding of the Holy Spirit and the saints and especially paying attention to the early holy church, the mother and teacher of us all. ${ }^{16}$

The agreement of early January 1432, and of St. James' day synod of 1434 both touched the two issues concerning the cult of saints, the questions of religious practice and intercession. Jan Rokycana, who at the January synod led the joined Prague

\footnotetext{
16 “...secundum intellectum spiritus sancti et sanctorum, praecipueque attendentes matrem magistramque omnium nostrum sanctam ecclesiam primitivam.” Quoted from Nejedlý, Prameny k synodám strany pražské a táborské, 7 (my translation).
} 
Hussite and Orphans' party, defended the intercession of saints and the benefits of the appeals of the faithful and their prayers to saints in the article 9 and 13 of the Prague synod agreement of 9 January $1432 .{ }^{17}$ The articles stress the need of both respectful approach towards the saints, and of a moderate attitude in its cultic expressions, including keeping the saints' feasts in all modesty and refraining from excesses: sed in moderamine prout decet ad sanctos se habere (but in moderation just as one ought to behave toward the saints) and foret respectus ad sanctos (there should be respect toward the saints).

The basic framework of the articles is inspired by earlier conservative views within the Hussite camp, but their "moderate" warnings against the cult of saints that threatens to outshine God due to inappropriate and immoderate conduct, echoes more radical ideas in the background. With the exception of the article on saints' feasts, St. James' synod of 1434 confirmed all the points in favour of the cult, ${ }^{18}$ reintroduced alms and prayers, but again repeated warning

\footnotetext{
17 "Articuli magistrorum et sacerdotum antique civitatis Pragensis per regnum Bohemie sub anno Domini Millesimmo. CCCC. Tricesimo secundo," in Confessio Taboritarum, ed. Amedeo Molnár - Romolo Cegna (Rome: Nella sede dell' istituto Palazzo Borromini, 1983), 343344 and 345. Halama, Otázka svatých, 46, ft. 149.

${ }^{18}$ Zilynská, Husitské synody v Čechách, 115-116, 118.
} 
against simony and the greed of priests, who attempt to misuse the cult of saints for their own benefit. The synod insisted on the priority of the divine mandate before the human one.

Regardless of the objections raised by the radical Taborites and whilst setting bounds to the expressions of cult, the emerging Utraquist party around Jan Rokycana (drawing its authority from the negotiations on the Compactates Treaty of 1436 between the Council of Basel and the Hussites that concluded the Hussite wars) returned to the Catholic-oriented views concerning the intervention of saints in human Salvation. According to the articles, the saints are capable of intercession on behalf of the faithful sive eorum disposicione, i.e. according to their individual competence. The radical rhetoric was abandoned, for the time being.

Although in general the Taborite party held a positive view on the early Christian saints and saw them as authority and model to follow in life and cult, they differed from the rest of the Hussites in their view of why, and how one should venerate them. In 1420-1424, the Taborites formulated their view on the saints' cult, a view that refutes the external expressions of cult that for radical preachers was a cultus 
inordinatus (a not legal cult), ${ }^{19}$ such as celebrations of saints' feasts, fasting, vigils. It also reveals distrust towards those saints, who were not named in the New Testament, and doubts the saints' competence in intercession. ${ }^{20}$ Consistently with the Taborite teaching of the 1420s, the Taborite theologian Nicolas Biskupec of Pelhřimov compiled respondent treatises to both above-mentioned articles of 1432 and 1434. He summarised his arguments in De invocatione sanctorum in coelis of 1434 that - on the basis of authority of the Bible expressed the impropriety of those forms of saints' veneration that should be reserved only to God, denied intercession, and cast doubts on their role in Salvation:

...from the authority of the doctors it is clear that invocations and prayers are (forms of) cult that are appropriate only for God... and that from the authority of Scripture ...it cannot not be inferred that saints in heaven should be asked for help and intercession by praying and through invocations, as priests and others were used to teach, leaving the people to suffer in great superstition and perfidy. Therefore we do not pray and

\footnotetext{
${ }^{19}$ Jan N. Sedlák, Liturgie u Husa a Husitův, Studie a texty k náboženským dějinám českým 2.5 (Olomouc: Matice cyrilometodějská, 1915), 161.

${ }^{20}$ See Halama, Otázka svatých, 39, ft. 116.
} 
invoke the saints, nor do we seek help from them and thus impede the cult that only God deserves... Following Augustine we say that it is appropriate that the saints should be honoured and imitated, but the saints are to be honoured through imitation, but not venerated through religion. We thus do not deny the assistance of saints that supports the people in the Church Militant, but by no means do we assert that their assistance is demanded by God. ${ }^{21}$

${ }^{21}$ Halama, 51: "Circa invocacionem sanctorum in celis percipientes ex communi sententia doctorum, quod invocacio sive oracio saltim proprie dicta est cultus soli deo exhibendus, et non videntes expressam Scripturam legis sub eterna dampnacione obligantem ad tenendum pro fidei articulo, quia sancti in celis a fidelibus his viantibus pro suffragio et intercessione necessario sint orandi aut invocandi modo, quo communiter sacerdotes et alii populares ex eorum instruccione consueverunt, et notantes populum per hoc in magna supersticione et perfidia continue laborare, ea intencione ipsos non oramus nec invocamus, nec suffragia eorum ab eis postulamus, ne cultum soli Deo debitum ipsis impendamus, quamvis sicut decet eos dicamus honorandos ac imitandos, scientes secundm Augustinum, quod sancti sunt honorandi propter imitacionem, sed non adorandi propter religionem. Suffragia autem sanctorum non negamus, quibus suffragantur hominibus in ecclesia militante, et ea non asserimus a Deo nullatenus postulanda."

Cf. František M. Dobiáš, and Amedeo Molnár, ed. Mikuláš z Pelhřimova. Vyznáni a obrana Táborů (Prague: Nakladatelství ČSAV, 1972), 115f, where he writes that saints were given to us for imitation, not veneration, ... no one deprived of his body is a reliable a true mediator between God and faithful except Christ, nor defender or intercessor for sinnful in front of God. See also Jan z Př́bramě, Život kněži Táborských, ed. Jaroslav Boubín, Podbrdsko fontes, (Př́ibram: Státní okresní archiv Př́ibram, 2000), 56: "Panna Maria ani jiní světí nemohú nám spomoci, Abychme nevolali k svatým na pomoc, Kosti a těla svatých ohavili. Obrazy zkazili.” [The 
Nicolas and the Taborite party honoured the apostles as witnesses and protagonists of the ecclesia primitiva, an ideal community that they themselves wanted to emulate. They accepted saints as important exempla worthy of commemoration, and imitation in life, but they saw cult, and teaching on intercession and purgatory as a dangerous deceit by the greedy priests. Even though in 1432 and 1434 important steps were made in bringing the teachings of the Taborites and Rokycana's Utraquism close to each other, the questions of intercession and the cult of saints remained dividing points.

Nicolas' ideas were developed in the writings of Petr Chelčický (c. 1390-1460), an original thinker, close to the radicals, in his writings of 1430s-1440s. The founding ideology of what came to be the Unity of Brethren takes on a similar critical view on the cult of saints, refusing the intercession of the Virgin Mary and the saints. It also blames priests for trading with the holy and for favouring saints

\footnotetext{
Virgin Mary or other saints cannot help us...We should not ask saints for help...they violated bones and bodies of saints...images destroyed]. For the distinction of the church fathers between worship owed to Christ and that of saints, see Kenneth Woodward, Making Saints: How the Catholic Church Determines Who Becomes a Saint, Who Doesn't and Why (New York: Touchstone 1991), 58.
} 
before God, when the source of their beneficiary power - to which he consents - only comes from God and through God. ${ }^{22}$ Petr sees saints as co-actors, and partakers of grace, but argues against the saints' competence to redeem sins, denies the use of images in cult, and, as Nicolas, declares that the only proper way of honouring saints is by leading a good, saintly life imitating them. He resolves that keeping the memory of saints is beneficial as it can inspire faithful to lead saintly lives:

Following the creed, we confess that we keep hope in saints as the co-heirs of the future good and we believe in their benefits and help; and we thank God for whichever good things and help God has laid in them for the just here (on earth). As saints can provide no other benefit for those living here than is given in them through God...

...(saints) should not be venerated any other way than by people becoming saint themselves. They should be honoured by us through our saintly lives, ...(we should

${ }^{22}$ Halama, Otázka svatých, 60-61. 
be) following them in their conduct, and deeds, of which they left us true examples... ${ }^{23}$

Whereas the mentioned critique may have caused the cult of saints to loose attraction for some, the idea of saints representing the ideal Christian life for the contemporaries persevered in Utraquism as well as the Unity of Brethren.

In pointing out the importance of a genuine imitation of saints in life, Nicolas and Petr might actually have drawn on the earlier thought of Jan Hus. Already before his sett-off to Konstanz, Hus was at least aware (if not supportive) of the christomimetic potential of his future fate. ${ }^{24}$ In a letter written in the fall of 1414, he speaks of Christ's death as an exemplum given to the followers of Christ - those who suffer for him and for our salvation. "Why should not we suffer the same way as did Christ himself?” he asks. Hus had a first-hand experience with this notion. He was accused by the Council of Constance for having held a commemoration for three beheaded laymen in Prague in 1412, who exhorted by his

\footnotetext{
${ }^{23}$ Jaroslav Boubín, ed., Petr Chelčický. Siet viery, Sbírka pramenů k náboženským dějinám 3 (Prague: Historický ústav, 2012), 328, and 330. Long passages on saints can be found in chapters 30-51, p. 295-331. They have been inspired by Nicolaus of Pelhrimov's Confession of the Taborites, Halama, Otázka svatých, 61.

${ }^{24}$ Hack, "Heiligenkult im frühen Hussitismus,” 134, 148.
} 
sermon in the Bethlehem chapel had walked around Prague provoking turmoil. ${ }^{25}$ Although he was not personally responsible for this "precedent-setting" act, ${ }^{26}$ and may have not even been present, he was surely aware of what had happened. Through the imitation of Christ's suffering, Hus, as he approached death did not understand the saints' cult as a commemoration of the past, nor as an intercession for the future. He rather saw sanctity as a model for the present time and a true re-enactment of the ecclesia primitiva in his own day. This hagiographical matrix was a concept acceptable also to the radicals, and fitted well into the early period of the Hussite movement, when there was a sufficient number of martyrs of faith to be remembered. ${ }^{27}$ The cults of the Constance martyrs, Hus and Jeroným of Prague, matched this concept of sainthood perfectly. Christ, the apostles and early Christian martyrs who gave their lives for their faith in the time of persecution represented an appropriate parallel to the forming cult of the Hussite martyrs, as expressed in a sermon by Jan Želivský in $1419 .^{28}$ It may seem to be a paradox, but

\footnotetext{
${ }^{25}$ Hack, "Heiligenkult im frühen Hussitismus,” 142-3.

${ }^{26}$ David Holeton and Hana Vlhová-Wörner, "A Remarkable Wittness to feast of Saint Jan Hus," Bohemian Reformation and Religious Practice 7 (Prague: Filosofia, 2009), 157, ft. 5.

${ }^{27}$ Hack, "Heiligenkult im frühen Hussitismus," 146-7.

${ }^{28}$ Molnár, Jan Želivský, 131.
} 
the need to establish an acceptable theological and hagiographical framework for a dignified commemoration of the contemporary Hussite martyrs may, in fact, have contributed to the easing of the views on some aspects of the liturgical and cultic commemoration of saints.

The consolidation of the teaching on saints in Utraquism

Facing the possibility of a reconciliation with the Basel Council, Rokycana and the Utraquist party turned its back on the views of the Taborites. For the consolidation of the position on saints in Utraquism, now the strongest party of the movement, the results of the Compactate Accord of 1436 and the series of regulations enforced in the period of 1437 to 1444 were imporant. The agreement with the legates of the Basel council authorised by the conservative University masters imposed the return to traditional forms of religious practices connected to the saints' cult in Prague, such as ceremonies, the handling of relics, feasts, pilgrimages and 
images; in effect, many images of saints returned to the Prague churches as was noted in Aeneas Silvio Piccolomini's History of Bohemia. ${ }^{29}$ But the Hussite iconophobia and uneasiness towards saints was not easily forgotten - especially the problem of images was treated carefully as the Utraquist Church orthodoxy was formed. We can trace this cautiousness in the Czech Articles on the keeping of the Basel Accord, a vernacular executive instruction of 1437 based on the Compactate Accord. It follows closely the template written in Latin by the Council legates, ordering the return to the traditional forms of cult. It differs from the original only in the passage on images, where it gives a more precise explanation of their role in the cult, and instructionabout how to approach them:

Concerning the images in churches to be of Christ and the Virgin Mary and other saints. And the priests are to teach the people according to the provisions of the Holy Church, which says De consecrat. Dist. III: good images ("poctivé obrazy”, honourable, worthy) are not called gods by Christians, nor worshipped as gods, nor

\footnotetext{
${ }^{29}$ Alena Hadravová, Dana Martínková, and Jiř́ Motl, ed., Aeneae Silvii Historia Bohemica / Enea Silvio Historie česká (Prague: Koniasch Latin Press, 1998), 169.
} 
is faith put in them to bring salvation, nor any future judgement expected from them, [they are] merely revered for the commemoration of sainted forefathers, however neither they nor any creature are to be worshipped as a god. As Saint Gregory and other sainted fathers proclaimed, we have images put in front of our eyes so that seeing them bodily should move us so that whensoever we behold an image we shall raise our minds to that, whose image we see. We may kneel in front of it in reverence, but we pray only to the One, whom we remember through the image of seeing him born, martyred or seated on the right (of the Father). And sometimes the painting is like the word, bringing to memory the son of God, bringing to our mind not sorrow, but joy of Resurrection.... ${ }^{30}$

An important corrective to the Latin document, the text yields to the memorial function of saints' images, but limits the honouring of saints through them - all reverence must be directed only to Christ. The text illustrates the shift in understanding, which the images of saints underwent as a

\footnotetext{
${ }^{30}$ Michal Šroněk, "Artykuly na držení kompaktát a teorie obrazu v době pohusitské,” Umění 5-6 (2010), 384-387, (trans. Silvia Hromádková).
} 
result of the polemic on the status of saints and images in the cult. Based on the authority of St. Gregory the Great, images of saints are here deprived of any cultic and intercessory power; they function only as media of memory. The faithful may kneel before images of saints, but prayers are reserved only to Christ, whose representations in his human form and suffering are welcome to evoke religious enthusiasm and empathy. The same text also demands the return to pilgrimages, which used to be criticised by Hussite theologians (e.g. Jacobellus of Stríbro). Following the agreement, the Council legates tried to re-introduce ceremonies that involved relics after $1437 .^{31}$ This was followed by the conservative theologians Jan of Př́bram and Prokop of Plzeň, who in the 1440s promoted the traditional forms of the cult of saints. This strategy did not hold on for long. Rokycana found relics and pilgrimages inacceptable, criticised them openly, and his fellows chose rather to ignore them. ${ }^{32}$

31 Kateřina Horníčková, "Memory, Politics and Holy Relics: Catholic Tactics amidst the Hussite Reformation," in Materializing Memory Archaeological material culture and the semantics of the past, ed. Irene Barbiera, Alice M. Choyke, and Judith A. Rasson, BAR Series (Oxford: Archaeopress, 2009), 97-103.

${ }^{32}$ Following Jaroslav Boubín - Jana Zachová, Žaloby katoliků na Mistra Jana z Rokycan (Rokycany Rokycany: Státní okresní archiv, 1997), 51, 28, Rokycana personally forbid processions with relics. Blanka Zilynská, 
In the 1440s, when the conservative (Utraquist, but proCatholic) party of Menhart of Hradec steered Prague, further steps were undertaken to the restoration of the cult of saints in its Catholic extent. ${ }^{33}$ The key moment to entrench the conservative attitude to saints is the Kutná Hora Utraquist synod of 1441 and the polemics with the Taborites that arose around its pro-Catholic perspective on cult. ${ }^{34}$ Its results were confirmed by the articles of land councils in 1441 (Čáslav) and 1444 (Prague) that sealed the official teaching of Utraquism and the defeat of the Taborites on the issue. The political situation was different than in the 1430s - the archbishop-elect Rokycana is now in the position of an official authority, whose task is to bring the Taborites to discipline, and he clearly cannot allow any open disobedience. The synod articles of 1441 were directed against their teaching and embrace - with Rokycana's support - a more favourable standpoint towards the pro-Catholic views of

\footnotetext{
"Ansichten der böhmischen Utraquisten des 15 . Jahrhunderts zur Wallfahrt," in Wallfahrt und Reformation / Pout' a reformace. Zur Veränderung religiöser Praxis in Deutschland und Böhmen in den Umbrüchen der Frühen Neuzeit, Europäische Wallfahrtsstudien 3 (Frankfurt am Main: Peter Lang, 2007), 79-108. On a rare occurence of a consecration of relics in Utraquism, see Kateřina Horníčková, Between Heaven and Earth: Treasure in Late Medieval Bohemia, Ph.D. Diss., (Budapest: Central European University, 2009), 174-6, 186.

33 Zilynská, Husitské synody v Čechách, 104.

${ }^{34}$ Nejedlý, Prameny k synodám, 5 and 7-8.
} 
Rokycana's former opponent, Jan of Př́bram. The early church (ecclesia primitiva) is not mentioned once as an authority, and no division between human and divine mandates can be observed in the text. The parts on saints comply fully with the Catholic practice, including all forms of veneration, and fasting in the full extent of the Catholic habitus. The articles use the same arguments as those of 1432, but now the restrictions that should have kept the cult moderate are left out. ${ }^{35}$

The situation changed after the overtaking of Prague by George of Poděbrady in 1448 that caused the fall of the conservative leaders and the following defeat of the radical Tábor in 1452. Rokycana - now a sole non-Catholic authority - can now turn back to the Hussite arguments for inspiration, without the need to compromise. He is concerned with the moral conduct of priests, redundancy of pilgrimages and relics, and excessive cultic practices, as his Catholic opponents report. The accusations of the Catholics against Jan Rokycana (1461) recount him as a wyclifite, who keeps complaining about the persisting "false belief in the intercession of the saints, although it is known that the saints

${ }^{35}$ Nejedlý, Prameny k synodám, 13-14. 
alone cannot forgive sins, only Christ does.” ${ }^{36}$ He repeats older arguments of the radical Hussites about simoniac priests earning money on the cult of saints, about people, who like drinking, being merry and sinning on the feasts, and wandering around on pilgrimages. Rokycana did not go back to the Taborite refusal of saints, but as the Hussite critics earlier, ${ }^{37}$ he suspected that the returning practices of the cult of saints might outshine the exclusive position of the Corpus Christi in Utraquist religious practice. $^{38}$ Particularly pilgrimages and the carrying of relics and images troubled him, ${ }^{39}$ which indirectly confirms that the Catholics at the time intensified their promotions of traditional expressions of

\footnotetext{
${ }^{36}$ Boubín - Zachová, Žaloby katoliků, 48-50.

${ }^{37}$ Based on Jacobellus and Matthew, Hussite authors observed the decline of the cult of saints as a consequence of the preference for the Corpus Christi. Halama, Otázka svatých, 18. Laurentius of Březová sees the images of saints as a counteract to the Hussite cult of the Eucharist: (the Catholic army invading Kutná Hora) "took away the newly-erected sanctuary for the Corpus Christi (in the church) and destroyed it to pieces. Quickly, (Kutná Hora burghers) exhibited images of Christ or saints on the houses that were earlier hidden away so they could show the soldiers (of the anti-Hussite party) that they were not from the sect of Prague heretics. And with a great joy they placed these images again in the churches upon the altars...swearing at the Taborites, the Prague party and wycliffists..." František Heřmanský, ed. Vavřinec z Březové. Husitská kronika. Písen̆ o vitězství u Domažlic (Prague: Svoboda, 1979), 275-6.

${ }^{38}$ František Šimek, Postilla Jana Rokycany, vol. 1 (Prague: Komise pro vydávání pramenů českého hnutí náboženského, 1928-9). See Hussite origin of this idea in Bartlová, Understanding Hussite iconoclasm, 121.

${ }^{39}$ Boubín - Zachová, Žaloby katolikiơ, 51,28,
} 
saints' cults. ${ }^{40}$ With a clear intention to denounce him, the Catholic articles exaggerated Rokycana's animosity to the saints by accusing him of preaching against saints and the Virgin Mary - Rokycana should have expressed his view in public by disposing of a statue of the Virgin Mary that stood on the main altar in the Tyne church in Prague. In his sermons, whilst repeating arguments against excessive expressions of the cult of saints to the detriment of the centrality of Christ, and his reservation towards their capability to redeem sins, Rokycana actually gave saints a great deal of authority as important moral exempla. In his parable of ecclesiastical hierarchy, he compared Christ to the sun, the Virgin Mary to the moon, a position she deserves for her humility, and saints to the stars for their great virtues and good deeds. $^{41}$

In spite of Rokycana's efforts, there was little central authority that would be able to properly and equally enforce a synodal regulation, especially when Rokycana maintained a somewhat cautious distance in the matter. Officially, the cult of saints was following the Catholic pattern in its pre-Hussite

\footnotetext{
${ }^{40}$ Halama, Otázka svatých, 59, ft. 192-4. Michal Šroněk, "The Veil of the Virgin Mary. Relics in the Conflict Between Roman Catholics and Utraquists in Bohemia in the 14th and 15th Centuries," Uméní 57.2 (2009), 118-139.

${ }^{41}$ Šimek, Postilla Jana Rokycany, I, 55-6.
} 
extent, in reality it re-emerged from the Bohemian religious controversy of the first half of the $15^{\text {th }}$ century in a profoundly transformed way. As Uhlír observed, for a part of the faithful the cult of saints remained an empty enterprise. ${ }^{42}$ Utraquist theologians tried to curb the cult, especially regarding pharisaic praying, fasting and donations to redeem sins, clerical ethics, trading with the holy, improper celebrations of feasts, and keeping faithful morals ${ }^{43}$ in reaction to the ostentatious promotion of Catholic ceremonies. In regions under Utraquist hegemony, contrary to the symbolic uses and the distrust to the cult, intercession and redemption from sins through saints persevered among the popular attitudes, whilst in the Catholic parts, the external expressions of the cult turned into symbolic manifestations.

The cult of saints may have lost some of its attractiveness, but it still represented an ideal pattern for the preaching and instruction on ideal Christian conduct. In Utraquism, the

\footnotetext{
${ }^{42}$ Uhlír, Česká reformace: svatost a/nebo zbožnost, unpag. (between ftnote 13 and 15)

43 Sermons and written polemic against the cult of saints, written around 1517 by priest Martin of St. Henry Church in Prague: Knížka proti ošemetné poctě a pokrytí svatých od kněze Martina, faráre u svatého Jindřicha $v$ Praze sepsaná i kázaná okolo léta 1517. a nyní obnovená a na světlo vydaná skrze kněze Jana Štelcara Želetavského z Želetavy, faráre $\checkmark$ Velké Bystřici lita páně 1593. K niž jsou staré písně přidané, the edition reprinted in Halama, Otázka svatých, 169-180 (old print in the Library of the National Museum, Prague, sign. 37.D.29).
} 
saints were valued preferably for their moral reputation and exemplary perseverance in faith, not for events in legends or miracles. ${ }^{44}$ The idea of imitating the early Christian saints in contemporary life survived as an important current in the Utraquist and Unitarian teaching. They envisioned a reemerged ecclesia primitivaas a parallel existence of the "saints of our days", living according to God's law as the righteous in the society. ${ }^{45}$ The concept guided the selection of saints in Utraquism, linking the early Christian past and the present.It also created a framework for the enlargement of the body of Utraquist saints.

With occasional hesitation, saints (unlike relics ${ }^{46}$ ) returned into Utraquist religious practice, even though the parish communities maintained different views on cult expressions. ${ }^{47}$

\footnotetext{
${ }^{44}$ Woodward, Making saints, 62.

${ }^{45}$ Knižka proti ošemetné poctě a pokryti svatých od kněze Martina, 168, 171-2. Cf. similar concept in Luther, Ulrich Köpf, "Protestantismus und Heiligenverehrung," in Heiligenverehrung in Geschichte und Gegenwart, ed. Peter Dinzelbacher, und Dieter R. Bauer (Ostfildern: Schwabenverlag, 1990), 327.

${ }^{46}$ Horníčková, In Heaven and on Earth, 176-7.

${ }^{47}$ Zikmund Winter, Kulturní obraz českých měst: Život veřejný v XV. a XVI. věku, vol. 1. (Prague: Matice česká, 1890), 441, where in 1468 the hetman of the Prachatice region complained about farmers of the Prachatice parish for not contributing money for an image in their church because they "do not mind if there will be any, as earlier they destroyed them and poked out their eyes , as we can still see today in the church of St. Peter (in Prachatice). If they would be asked to contribute for the
} 
As part of the Catholic - Utraquist agreement, the Utraquist church adhered to the pre-Hussite Prague diocesan rule that determined the general structure of the feasts in the liturgical year. The Hromnice synod of 1524 confirmed the feasts of saints observed by the Utraquists. ${ }^{48}$ These included Christ's, and a selection of the Virgin Mary's feasts, the feasts of angels, All Souls, the saints mentioned in the New Testament, St. John the Baptist, St. Lawrence, St. Mary Magdalen, St. John Hus and of the Bohemian patron saints; without Hus,

sanctuary for the Eucharist they would not protest, but they do not like to see images in churches and consider them blasphemous...”

48 “...též také swátkowé výročzní, jako Krysta Pána Narození, Nowé létho, Třzí Králůw, Hromnicz, Zviestowání Panny Marye, Wzkřzíssení geho na nebe wstaupení, Ducha Sv. Seslání, Svaté Trogicze, Tiela Božího, na nebe wzetí Panny Marye, angelůw Božích, wssech swatých, Swátkowé apoštolsstí, ti kteřzíš základ w Zákonie Božím magí, $\underline{S^{0} \text { Jana Křztitele, }}$ Marye Magdaleny, $\mathrm{S}^{0}$ Wawřzincze, Mistra Jana Husy, y giných diediczúw Czeských zachowáwáni býti magí. Giní pak swátkowé v nedielské dni přzipomínáni býti mohau.” Chronicle of Bartoš of Prague [Bartoš Písař], Kronyka o pozdwiženj a Bauřzcze Pražské, National Library in Prague, shelfmark XVII.D.5, Manuscriptorium site, visited 20.1.2014: http://www.manuscriptorium.com/apps/main/index.php?request=show tei _digidoc\&docId=rec1352978283_42\&client=\&dd_listpage_pag $=212 \mathrm{v}$, fol. 13v. The problematic expression diediczúw Czeských [Bohemian heirs] and less outspoken mentions of Bohemian patrons in other Utraquist synodal texts and correspondence probably led Halama to believe that the veneration of the Bohemian patrons was limited to only St. Wenceslas. Ota Halama, "Utrakvistická úcta k českým světcům," in Světci a jejich kult ve stredověku, ed. Petr Kubín, Hana Pátková, Tomáš Petráček (České Budějovice: Ústav dějin křest’anského umění KTF v Praze a Tomáš Halama, 2009), 194. A different opinion is maintained by Václav Žůrek, Officia svatých v českých graduálech 16. století, paper held at the Bohemian Reformation and Religious Practice Conference in June 2012, unpag. Quoted with the author's permission. 
these were naturally also honoured by the Bohemian Catholics next to other saints. The synod articles forbid misbehaving during the feasts and states that other feasts should be held on Sundays, so that the labourers' trade would not be harmed.

Probably the most apparent evidence of the return of the saints was the re-appearance of images in churches. The formal characteristics give the impression that the images too reflect the purported "emptiness" of the cult. Recently, a new interpretative framework has been suggested for a style of "downfall" by art historians for the Bohemian saints' imagesof the fifteenth century. According to this view, the representations refrain from decorativeness and mimesis in order to "clean" images from deceptive illusions of reality and beauty that may lure the faithful to idolatry. ${ }^{49}$ Utraquist altarpieces $^{50}$ comply with this hypothesis - they concede

${ }^{49}$ For this concept see Milena Bartlová, Poctivé obrazy (Prague: Argo 2001), 48. Milena Bartlová, "Renaissance and Reformation in Czech Art History: Issues of Period and Interpretation,” Uměni 59 (2011), 2-19. The discussion on the nature of the "modest" forms of artistic expression (both on the Hussite and Catholic sides) and the relation of "formal simplicity" to the critique of the cult is still open, see critical remarks to this concept in Milena Bartlová, Pravda zvitězila. Výtvarné uměni a husitství 13801490 (Prague: Academia, 2015), 156, 175, 192, 214 and passim.

${ }^{50}$ Openly Utraquist altarpieces were targeted in the Counter-Reformation. Some survived in now Catholic churches, although they were often transferred to filial churches or less important places. More systematic research of their provenance and interpretation has not been done and would be hindered by a limited accessibility of written evidence. I am 
through their rough style and modest decoration that they are mere representations of their originals, and the products of human hands. They seem to share certain general characteristics: the viewers' attention is directed to Christ or Eucharistic motifs in the centre. Saints' figures are moved to the altar wings, that is to a secondary position. Miracles, relics and narrative scenes from legends are generally omitted. Early Christian saints, Bohemian patrons, and Hus are depicted at their martyrdom or as iconic standing figures, fit for didactic and memorial functions.

The Cult of the New Martyrs and the Authority of the Forefathers

Written sources convey that a cult arose around Jan Hus already soon after his death in Constance. ${ }^{51}$ Jacobellus of Stříbro held sermon on Hus and the Prague and Olomouc martyrs in the spring 1416. ${ }^{52}$ Adding Jeroným of Prague later,

considering here only those works, where the Utraquist provenance is known or generally accepted by scholars.

${ }^{51}$ Overview in Jan Royt, "Ikonografie Mistra Jana Husa v 15. až 18. století,” 405-7. On liturgical commemoration see Holeton and VlhováWörner, "A Remarkable Wittness to feast of Saint Jan Hus," 156-7.

${ }^{52}$ Hack, "Heiligenkult im frühen Hussitismus,” 138, ft. 66. 
he called both Hus and Jeroným the "new martyrs" (sermo...in memoriam novorum martyrum) in his preaching. In December 1416, a letter written by an Olomouc canon reported public memorial feasts with sung hymns and martyrs' anniversaries comparing Hus and Jeroným to St. Lawrence, St. Peter and early Christian martyrs taking place on the first anniversary of Hus death in $1416 .{ }^{53}$ Old Bohemian Annals inform us on images of Hus and Jeroným carried on the Prague streets, the Constance Council sources of 1418 on the songs about them and images in churches, and the Basel legates witnessed a sung Latin Eucharist on the feast-day of John Hus' martyrdom in $1433 .^{54}$

Next to the liturgical commemoration, images and songs became an integral part of promoting of St. Jan Hus as saint. Even when concerned about improper use of images in the

\footnotetext{
${ }^{53}$ The letter of Olomouc cannons of December 1416, "Pro Iohanne Hus et Ieronymo ...faciunt festivitates et cantant "Gaudeamus" et alia tamquam de martyribus, comparantes eosdem meritis et penis sancto Laurentio martyri et ipsos preferentes sancto Petro et aliis sanctis," Holeton and VlhováWörner, "A Remarkable Wittness to feast of Saint Jan Hus,” 156, ft. 3. Citing Howard Kaminsky, A History of the Hussite Revolution (Berkeley \& Los Angeles: University of California Press, 1967), 162-69.

${ }^{54}$ David Ralph Holeton, “Oslava Jana Husa v životě církve," in Jan Hus na přelomu tisíciletí, 83-111, especially 84-92. Royt, "Ikonografie Mistra Jana Husa v 15. až 18. století,” 405-6. Summarised by Michal Šroněk, "Comput digital and Jan Hus as Defender of the Faith," Uméni 61.1 (2013), 2-22, and Holeton and Vlhová-Wörner, "A Remarkable Wittness to feast of Saint Jan Hus,” 156-7.
} 
cults, the Utraquists were aware of their power to communicate in public the fama of the to-be saint. Hus' public death prompted written accounts of the event, which, on the Bohemian side, carried distinct hagiographic features. An eye-witness report on Hus' death by his student Petr of Mladoňovice written in late 1415 or early 1416 uses deliberately Christomimetic and hagiographical approaches to glorify Hus as martyr, namely the allusion to Christ's passion. ${ }^{55}$ Under the name of Passio Joanni Hus, the Mladoňovice's text was read on the Bohemian Martyrs' feast in the Bohemian churches. Petr's text was followed before 1430 by Passio Johannis Hus by Johannes Barbatus, another hagiographic text on Hus, where a particular significance was given to his affinity to St. Lawrence, who was burnt by fire as well. $^{56}$

As evidence of the notion of Hus' sanctity, in his sermon of 1419, Jan Želivský, a leading radical preacher from Prague,

${ }^{55}$ Hack, "Heiligenkult im frühen Hussitismus," 131.

${ }^{56}$ Passio Johannis Hus cum epilogo Jacobelli de Missa, manuscript no. XI D 9, Prague, Národní knihovna, 215r, website visited 20.1.2014, http://www.manuscriptorium.com/apps/main/index.php?request=show tei _digidoc\&docId=set20060315_118_42\&client=direct\&dd_listpage_pag=2 $\underline{13 v}$. Cf. "Passio Johannis Hus secundum Johannem Barbatum," in Fontes rerum bohemicarum, ed. Václav Novotný, vol. 8 (Prague: Nákladem nadání Františka Palackého, 1932), 22. Cf. Fudge, Jan Hus, 206. 
glorified John Hus and Jeroným as saints, ${ }^{57}$ and linked them to the early Christian martyrs, St. John the Baptist, Peter, Paul, James and Lawrence and the Old Testament Job. As Hus could not be subjected to any traditional hagiography procedure, which was firmly in the hands of the pope (such as the writing of official vita, the acceptance of miracles, his translation, relics and canonisation), ${ }^{58}$ the association with a particular known saint's pattern was the logical way toprovide his cult with an unquestioned pattern of sanctity. In making Jan Hus a saint, the Hussite concept of the existence of "saints of our days” imitating early Christian martyrs in the present, played a key role. Undoubtedly, this idea was behind the representation on the wings of the altarpiece from St. Wenceslas church in Roudníky (District Ústí nad Labem), where Jan Hus is depicted together with St. Lawrence, St. Stephen, and St. James, in a unique preserved example of the altar veneration of Hus (Fig 1) made before $1486 .{ }^{59}$ Hus is accompanied by the early Church martyrs St. Stephen and St.

\footnotetext{
${ }^{57}$ Molnár, Jan Želivský, 131: “Ergo qui partitur propter causam Dei, est verus martir... qualiter Deus puniet, quos reprobat, cum sic punit, quos amat, ut sanctum Johannem Hus, Ieronimum..."

58 Šroněk, "Compus digital," 18, sees in Hus a new type of saint.

${ }^{59}$ MB (Milena Bartlová), V/ 17, “Křídla retáblu z Roudník,” in Umění české reformace, 136-7. Milena Bartlová, "Upálení sv. Jana Husa na malovaných křídlech utrakvistického oltáře z Roudník,” Umění 53 (2005), 427-444.
} 
Lawrence also in the initial S of the introit to the feast of Hus in the Kutná Hora Gradual of 1490-91, ${ }^{60}$ decorating a hymn written specifically to his feast.

The strategy of Hus' individual representations also places him into a recognised pattern of sanctity. It uses two concepts: the martyrdom for faith, and Hus as a prophet of the right faith. ${ }^{61}$ The earliest preserved image of Hus' burning in the Martinice Bible, c. $1430,{ }^{62}$ shows Hus' martyrdom in the margin of the beginning of the Book of Genesis, contextualising him as the first martyr - the "first light" of new faith. ${ }^{63}$ A figure of scholar-hagiographist holding a book, who is turning back to the burning Hus, seals the authenticity of the account. Due to some losses of depictions of Hus depictions in illuminated choral books, images of Hus'

${ }^{60}$ Vienna, Österreichische Nationalbibliothek, Musiksammlung Mus. Hs. 15492, fol. 285r, Barry Graham, Bohemian and Moravian Graduals, 1420-1620 (Turnhout: Brepols 2006), cat. no. 128, 561-68.

${ }^{61}$ On different aspects of Hus iconography see: Bartlová, "Upálení sv. Jana Husa," 427-444, Milada Studničková, "Jan Hus jako světlo prvého dne: K ikonografii Martinické bible,” in Slánské rozhovory 2010 - Česká husitská reformace, ed. Zdeněk Víšek, and Blažena Hrabánková (Slaný: Vlastivědné muzeum ve Slaném, 2011), 32-38, Šroněk, "Comput Digital," 2-22. On images of Hus in manuscript illumination, see Martina Šárovcová, "Jan Hus in Illuminated manuscripts of the Bohemian Rennaissance,” Bohemian Reformation and Religious Practice 8 (Prague: Filosofia, 2011), 288-316.

${ }^{62}$ Possible earlier depiction of Hus' burning by Sassetta in Siena 1423-4 has no direct relation to Bohemia or Hus' cult. Fudge, Jan Hus, 207-8. Royt, “Ikonografie Mistra Jana Husa,” 406.

${ }^{63}$ Studničková, "Jan Hus jako světlo prvého dne,” 32-8. 
martyrdom that as a rule decorate his feast in the Utraquist graduals constitues the most frequently preserved iconography for Hus. ${ }^{64}$ The martyrdom was also painted in the monumental form, as is testified by a discovery of mural painting with this subject in a church in Písek, dated after 1560 (Fig 2).

Less frequently, Hus' iconography as a saint used the theme of prophecy of faith to show him in the role of preacher, priest or theologian defending the truth. He is depicted either in liturgical context as a priest-defender of lay chalice (in a martyr or priestly garment, with a chalice), ${ }^{65}$ or as preaching the true faith, for which he was unjustly condemned. ${ }^{66}$ The latter is ingeniously expressed in the illumination for Hus' feast in the gradual of Litoměřice, 1517, where the illuminator aptly used the knowledge of traditional medieval iconography to portray Hus as the defender of faith

64 Šárovcová, "Jan Hus in Illuminated manuscripts of the Bohemian Rennaissance,” 288-316.

65 As on Chrudim predella (KH (Kateřina Horníčková), "V-18 Oltáŕ Zmrtvýchvstání Krista z Chrudimi,” in Umění české reformace, 96, 139), and possibly also in full figure on the wall painting in St. Lawrence church in Prague - Petrrín Hill, 1450s-60s, where the identification of St. John Hus is complicated by the destroyed parts.

(http://realonline.imareal.sbg.ac.at/detail/?archivnr=013403, consulted 16.12.2015). Another depiction of this type is Hus and St. Adalbert with a chalice on Vliněves altarpiece, Horníčková, "V-19 Deska z oltáře z Vliněvsi," in Uměni české reformace, 142-143.

${ }^{66}$ Šroněk, "Comput digital," 3. 
and victim of a false accusation. ${ }^{67}$ Remarkably, the painter adopted an actual composition of the Assumption of the Virgin for this Hus' apotheosis.

A rare hagiographic composition illustrates Hus in the role of a personal patron saint. Printer's signet in the 1520 edition of Hus' Explanations on Faith shows Hus with a halo dressed as a university scholar and teacher recommending the publisher of the book to Christ (Fig. 3) ${ }^{68}$ The scene is remarkably reminiscent of patronage scenes, where the work's commissioner is recommended to Christ through a saint intercessor. No other similar works is known to have survived the Counter-Reformation that targeted works offensive to the Catholic faith and, in particular, personal memorial monuments of this kind. ${ }^{69}$

The diffusion of the Lutheran Reformation in Bohemia since the 1520 s braced up more radical views. Luther's

\footnotetext{
${ }^{67}$ Šroněk, "Comput digital," 2-22.

${ }^{68}$ Mistra Jā[na] Husy kazatele slawneho Dieditze Czeskeho Dwanaczti Cžlankuo Wijry ... (Prague: Mikuláš Konáč z Hodiškova, 1520) (Knihopis 03266), fol. s6b. Petr Voit, "Česká a německá reformace v ilustraci české knihy první poloviny 16. století,” in In puncto religionis. Konfesní dimenze predbělohorské kultury v Čechách a na Moravě, ed. Kateřina Horníčková, and Michal Šroněk (Prague: Artefaktum, 2013), 148. Voit mentions another full-figure print of Hus by Erhard Schön with an inscription identifying him as God's martyr, made around 1520.

${ }^{69}$ Recognisable non-Catholic objects have been targeted and destroyed in the Counter-Reformation (after 1622/4) in an attempt to damnatio memoriae of the non-Catholic past.
} 
consent to Hus' ideas prompted new types of iconography that portrayed Hus as an enlightened intellectual and as a teacher in a university teacher's garment, with a book, ${ }^{70}$ distributing lay chalice, ${ }^{71}$ a hero and forerunner of the Reformation, rather than a saint. Similarly as Rokycana and the Hussite preachers, Luther held saints in high regard for their reputation, saw in them human models of proper Christian life, but complained about their cultic veneration, attempting to foster living saints instead of dead ones. In a response to the Unity of Brethren on the Sacrament in 1523, he consented to the Unitarian refusal of the intercession of (dead) saints on the basis of the lack of biblical support. ${ }^{72}$ This view supported the radicals in Bohemia from both the Utraquists and Brethren churches at the moment, when a conflict between both groups escalated as part of their internal confessionalising process. Utraquists then split under the influence of Luther in the course of the $16^{\text {th }}$ century, but in spite of partial lutheranisation, Hus' feast

\footnotetext{
${ }^{70}$ This type is used often in Lutheran and Brethren prints, e.g. Songs of Praise to God printed by Pavel Severýn of Kapí Hora and Jan Roh for the Unity of Brethren in 1541: Piesně Chval božských. Piesně duchownie ewagelitské (Praha: Pavel Severýn of Kapí Hora, and Jan Roh, 1541), KNIHOPIS, no. K12856.

${ }^{71}$ MŠ (Michal Šroněk), "IX-11, Martin Luther a Jan Hus podávají pod obojí saským knížatům,” in Uměni české reformace, 301.

72 Köpf, "Protestantismus und Heiligenverehrung," 327-8. The question remains if Luther was inspired to such formulations by the Bohemian case.
} 
continued to appear in their liturgical books during the second half of the $16^{\text {th }}$ century.

Although the events of 1412-1434 brought a number of martyrs that deserved commemoration, ${ }^{73}$ Jan Hus and Jeroným of Prague remained the central figures honoured in the Bohemian Reformation. Their cult became symptomatic of the Utraquist religious identity. In 1495, the Printer of the Prague Bible (Severin Kramář?) published the Bohemian Passional with vernacular hagiographic translations of the texts from the Legenda Aurea. To meet a demand, he also printed two hagiographic texts for the Utraquists and other dissenting churches in a separate quire, the Mladoňovice Passio of Hus and an additional text on Jeroným of Prague, to which he added woodcuts of their martyrdom. This supplement ${ }^{74}$ was sold together with the rest of the Passional to non-Catholic customers, whereas without it, the work would not disturb any patriotic Bohemian Catholics. The Passional managed to serve different religious groups without causing indignation, and, for the Utraquists, it filed Hus among the most popular saints in Bohemia.

\footnotetext{
${ }^{73}$ Hack, "Heiligenkult im frühen Hussitismus,” 146-7.

${ }^{74}$ MŠá (Martina Šárovcová), “Tzv. Jenský dodatek tištěného Pasionálu Jakuba de Voragine,” in Uméní české reformace, 166-8.
} 
In the $15^{\text {th }}$ and early $16^{\text {th }}$ century, the mining town of Kutná Hora tried to challenge the leading position of Prague as head of the Hustite movement in the kingdom. Whereas Prague had Hus, Jeroným and three martyrs of 1412, Kutná Hora officials tried to promote local martyrs to the Bohemian Reformation cults. These two attempts remained of local importance - any of these cults never spread beyond Kutná Hora region. On the bottom of the already-mentioned folio for the feast of Hus $\left(\right.$ July $6^{\text {th }}$ ) in the Kutná Hora Gradual, ${ }^{75}$ an event from the early period of the Hussite wars was depicted, where the Hussite miners together with their priest Jan Chůdek were murdered by being thrown to the mines. The initial shows the figures of St. Jan Hus, Stephen and Lawrence, making a parallel between the executed Hussite miners, and Hus with the early Church martyrs. The patriotic decoration demonstrating the ambition to promote local new martyrs was ordered by a mining official from Kutná Hora. ${ }^{76}$

\footnotetext{
${ }^{75}$ Vienna, Österreichische Nationalbibliothek, Musiksammlung Mus. Hs. 15492. Graham, Bohemian and Moravian Graduals, cat. no. 128, 561.

${ }^{76}$ Ordered by Michal of Vrchoviště probably for the local church of Holy Trinity near Kutná Hora. Milada Studničková, "Die Kuttenberger Gradualien,” in Die Länder der Böhmischen Krone und ihre Nachbarn zur Zeit der Jagellonienkönige 1471-1526, ed. Evelyn Wetter, Studia Jagellonica Lipsinensia 2 (Ostfildern: Thorbecke, 2004), 136. Graham, Bohemian and Moravian Graduals, 561-2.
} 
The second attempt to promote a local cult is preserved in two fragments of a lost gradual illuminated for the mining community in Kaňk near Kutná Hora in 1559-61. The fullpage illuminations to the feast of Jan Hus represent Hus' martyrdom together with two other events aspiring to a local cult, the unjust executions of Kutná Hora miners near Poděbrady and Křivoklát in $1496 .{ }^{77}$ The connection to Hus' feast is a clear attempt to establish the memory of the executed miners as Utraquist martyrs, although their execution did not have a religious, but a political background. ${ }^{78}$ The connection to Utraquism here was loose enough to enable the cult to revive in the CounterReformation: a small chapel erected in 1515-6 on the place of their execution near Poděbrady was turned into a Catholic pilgrimage church in 1662-6. ${ }^{79}$

\footnotetext{
${ }^{77}$ Fragments of Kaňk gradual, Prague, Národní Muzeum, NM 1A c 109. Used from the internet site: http://cantica.kh.cz/grad/?page=zlomky, no. 5. Šárovcová, “Jan Hus in Illuminated manuscripts,” 300-1.

${ }^{78}$ Martina Šárovcová, "The Execution of the Miners of Kutná Hora at Poděbrady and in Krrivoklát in 1496: on the Veneration of the Miners of Poděbrady in the Sixteenth Century." Bohemian Reformation and Religious Practice 10 (Prague: Filosofia, 2015), 259-278.

79 Adolf Wenig, "O památném dubu poděbradském," in České pověsti (Prague: L. Mazáč, 1932). https://cs.wikisource.org/wiki/\%C4\%8Cesk\%C3\%A9_pov\%C4\%9Bsti/O_ pam\%C3\%A1tn\%C3\%A9m_dubu_pod\%C4\%9Bbradsk\%C3\%A9m, consulted 26.6. 2013.
} 
In the sixteenth century, this idea of new martyrs continued in flexible ways. It was transformed in an original way on the epitaph-altarpiece of Nový Bydžov, after 1531, into a glorification of priests as modern saints. The altarpiece shows the Last Supper with a chalice in the central panel. On the outer side of the wings the apostle figures St. Paul and St. James stand with their feet touching the ground in a typical iconic rendering of saints on Utraquist altarpieces. On the inner parts of the panels instead of saints, two local Utraquist priests-brothers are shown standing on decorative capitals, in a beatifying posture blessing the sacraments (Fig. 4). ${ }^{80}$ In medieval paintings, consoles or capitals were reserved for saints and Old Testament figures, especially the Virgin Mary, indicating their specific position in the Christian cult. On the altarpiece of Bydžov we see a clear shift in the notion of saints - whilst the apostles are presented as humble figures and models of morality, ${ }^{81}$ thetwo local priests are likened to

${ }^{80}$ Kateřina Horníčková, and Michal Šroněk, "The Bydžov Altarpiece and Its Denominational Transformations,” Uměni 60.5 (2012), 373.

81 Jan Harasimowicz, "Evangelische Heilige? Die Heiligen in Lehre, Frömmigkeit und Kunst in der evangelischen Kirche Schlesiens,” in: idem, Schwärmergeist und Freiheitsdenken. Beiträge zur Kunst- und Kulturgeschichte Schlesiens in der Frühen Neuzeit, ed. Matthias Noller Magdalena Poradzisz-Cincio (Neue Forschungen zur schlesischen Geschichte XXI, ed. Joachim Bahlcke) (Cologne - Weimar - Vienna: Böhlau, 2010), 93-125. 
the saints through the way they are represented. The use of capitals refers to the priests' elevated status in the cult; they are the new pillars of faith, ${ }^{82}$ equal in their importance to the early Church saints.

Next to Hus, the composition of saints venerated by the Utraquists looks remarkably traditionaland rather exclusive. Special attention in the calendar is given to the community of early Christian saints, especially the New Testament saints, the Virgin Mary, Apostles and early Christian martyrs. In spite of the Hussite's doubting her intercession and relics, the Virgin Mary was the most honoured saint in Utraquism due to her closeness to Christ and evidence of his human origin. The number of her feasts in the Utraquist graduals exceeds those of Hus, whose feast is almost allways present testifying to his important position for Utraquist identity. ${ }^{83}$ Although the Virgin Mary is the most frequent saint in the graduals, and there are numerous altar images of Mary's motherhood, her

${ }^{82}$ Zdeněk David, Finding the Middle Way. Utraquists' Liberal Challenge to Rome and Luther (Washington: Woodrow Wilson Center, John Hopkins University Press, 2003), 126-127, cf. Pavel Smetana Bydžovský, Tento spis vkazuge, zie Biskupowee Biskupa / a Biskup Kniežij / a kniežij od rzádných Biskupuo swieceni Tiela a krwe Božij poswiecowati magij (n.p., 1543), KNIHOPIS K01396.

${ }^{83}$ Václav Žůrek, Officia svatých v českých graduálech 16. století, paper held at the Bohemian Reformation and Religious Practice, June 2012, unpag. Quoted with author's permission. 
cult in Utraquism would need a separate attention, exceeding the concern of this article.

After the Virgin Mary and Hus, the apostles (particularly St. Peter and Paul, and St. James), St. John the Baptist, and early Christian martyrs (St. Lawrence) were the most frequent saints, both in Utraquist graduals ${ }^{84}$ and monuments. ${ }^{85}$ In the Franus Gradual from Hradec Králové, dated $1505,{ }^{86}$ we find no less than seven offices devoted to the different apostles, together with a special feast of the Divisio apostolorum, the feast of St. Peter and Paul, and joint feast of the Apostles and Evangelists. They were joined by St. Mary Magdalen, who,

${ }^{84}$ Žůrek, Officia svatých v českých graduálech 16. století.

${ }^{85}$ For example altarpiece from Slavětín (National Museum in Prague, inv. no. HA 3.915/a,b,c, with St. Peter and James, St. Wenceslas, St. Procopios), Rohenice (church St. John the Baptist, Rohenice - Farní úrad České Meziříčí, inv.no. 5114, with St. John Baptist, Peter, Paul, John the Evangelist, Dorothy and Catherine). Kateřina Horníčková, "Oltář se svatostánkem mezi anděly a jeho geneze", in Středověký kaleidoskop pro muže s hůlkou, ed. Petr Sommer, and Eva Doležalová (Prague: NLN 2016), 324-332.

${ }^{86}$ Zpěvy na svátky svatých Franusova graduálu, Franus Gradual, Hradec Králové, Muzeum východních Čech, Ms. $\mathrm{Hr} 06$, http://www.clavmon.cz/limup/dbObsahRKP.asp?ID=195, consulted 11.12.2013. Feasts of the apostles, evangelists, martyrs and virgins(?), confessors, De lancea Domini (a Bohemian relic feast!), Dorothy, Procopios, Divisio Apostolorum, Mary Magdalen, Wenceslas, Margareth, John the Baptist, the Angels, St. Peter, St. Martin, St. Stephen, Paul, Adalbert, Vitus, John Ev., Peter and Paul, Elisabeth, James, Anne, Lawrence, Bartholomew, Matthew, Wenceslas (the second time), Michael, Ursula and 11 mil. Virginum, Catherine, Andrew, the Virgins, Cyril, and Methodius. 
although a sinner, was redeemed by true faith and penitence, as Rokycana puts it in sermon, ${ }^{87}$ which made her figure especially suitable for the Utraquist accent on morality.

The close connection between Hus and John the Baptist is visualised in the incipit to the feast of Jan Hus in the gradual of Lesser Town (Malá Strana) in Prague of 1572, where the scene of Hus' burning in bas-de-page is combined with the Decapitation of St. John the Baptist in the introit initial. On the margin, an illumination of the succession of the Reformation shows three medallions with Wyclif striking a spark, Hus burning a candle, and Luther holding a torch, pointing to the Lutheran-Utraquist background of the community. ${ }^{88}$

Other early Christian saints found in the Utraquist graduals and altarpieces are holy virgins, ${ }^{89}$ warriors and St. Anne. They represent universal models of Christian ethic, purity, matron-

87 "whatever sins you have if you have a true faith, God forgives you all the sins, as in the case of Mary Magdalen, to whom Christ said Your faith has saved you...” Šimek, Postilla Jana Rokycany, vol. 2, 563.

${ }^{88}$ Prague, Národní knihovna, XVII A 3 (Gradual of Lesser Town of Prague), pars prima, fol. 363r, MŠ (Martina Šárovcová), "XIV/7 Malostranský graduál pars prima," in Uměni české reformace, 446-8 (pl. on p. 447), Graham, Bohemian Graduals, cat. no. 70, 367-70.

${ }^{89}$ Altarpieces with holy virgins are preserved eg. from Tyne Church in Prague (with Apostels), St. Catherine and the Virgin Mary Churches in Chrudim (the second with Apostels), and panel painting from Litoměřice, Jaroslav Pešina, Česká malba pozdní gotiky a renesance. Deskové malírstvi 1450 - 1550 (Prague: Orbis, 1950), 120, 111, 112, 132. 
hood, and defence of faith, which kept their cult popular, although they were not attestedin the New Testament. In the case of St. Anne, the townsmen apparently did not resist the popularity of her late medieval cult that was particularly strong in urban societies. ${ }^{90}$ The altarpieces of the Virgin Mary's lineage, St. Anne and Holy Kinship, ${ }^{91}$ glorify Christ’s human lineage and conceptualise his incarnation as a prerequisite for his sacrifice, fully in correspondence with Utraquist Christocentric theology.

\section{The Claim on the Bohemian Patron Saints}

Whereas the cult of Jan Hus became a symbol of Utraquism in the confessionally divided land, the politically isolated Bohemian Utraquist church looked for confirmation of its legacy in the country's own religious past. Building on a Hussite Bohemocentric concept, ${ }^{92}$ the Utraquists tried to

${ }^{90}$ Kathleen Ashley, and Pamela Sheingorn, Interpreting Cultural Symbols. St. Anne in late medieval Society (Athens and London: University of Georgia Press 1990), 21-27.

${ }^{91}$ Altarpieces from Chrudim, and Kutná Hora, Pešina, Česká malba, 133, 126.

${ }^{92}$ František Šmahel, Idea národa v husitských Čechách (Prague: Argo, 2000). Petr Čornej, "Idea národa v husitských Čechách," in Jan Hus na prelomu tisiciletí, ed. Miloš Drda, František J. Holeček, and Zdeněk 
appropriate for themselves the Bohemian patron saints, a group of saintly intercessors (St. Wenceslas, St. Ludmila, St. Procopios, St. Adalbert, St. Sigismund and St. Vitus) formed in the $14^{\text {th }}$ century to express the attachment of local saints to the kingdom (with Prague as its most important cult centre). ${ }^{93}$ In this undertaking they confronted the Catholics, who were also trying to build a legacy on the traditions of the preHussite Bohemian church. ${ }^{94}$ The main point of conflict was the question whether these patrons communicated sub utraque or not. ${ }^{95}$ The Czech-speaking Utraquists naturally deemed them so, and, through these saints, imagined themselves as the legitimate heirs of the Bohemian cultic past. In particular, the symbolic political cult of St. Wenceslas was a point, where

Vybíral, Husitský Tábor Supplementum 1 (Tábor: Husitské muzeum v Táboře, 2001), 379-394.

${ }^{93}$ For a comparison with the development of regional (and political) cults in Central Europe and their visual representations, see Gerhard Jaritz, and Kateřina Horníčková, "Region, Saints, and Images (Central Europe, Middle Ages and Early Modern Period): Developments, Variety, and Difference,” in Different Europes, ed. Dick de Boer et al. (Turnhout: Brepols, forthcoming). On the Bohemian patron saints Petr Kubín, Sedm premyslovských kultů (Prague: Univerzita Karlova v Praze and TOGGA, 2011), esp. Ludmilla (81-123), Wenceslas (125-150), Adalbert (161193), Procopios (219-255).

${ }^{94}$ Jan Royt, "Renovatio regni. Zum Charakter der Kunst in Böhmen unter den Jagiellonen Wladislaw II und Ludwig II,” in Die Jagellonen. Kunst und Kultur einer europäische Dynastie an der Wende zur Neuzeit, ed. Dietmar Popp, and Robert Zuckale (Nuremberg: Germanisches Nationalmuseum, 2002), 228-9.

${ }^{95}$ Halama, "Utrakvistická úcta k českým světcům,” 190, 191, ft. 9. 
interests of both denominations vying for supremacy were confronted. ${ }^{96}$ When needed, however, St. Wenceslas' figure could stand as a symbol for the union of both, especially in political matters. ${ }^{97}$

St. Wenceslas exceptional position is confirmed by regular liturgical commemoration, sermons, and a number of religious monuments. ${ }^{98}$ He was the most popular Bohemian saint after Hus ${ }^{99}$ and a political symbol, used particularly in urban setting to advocate causes from urban political ambitions to religious unity. His figure (c. 1490) decorated the main hall of the town hall in Prague Old Town and the pavese shield from the town hall of Kutná Hora (c. 1485). On the latter, St. Wenceslas is shown with the Hussite symbol of chalice, and

${ }^{96}$ Josef Macek, Vira a zbožnost jagellonského věku (Prague: Argo, 2001), 80. The Hussites managed to overturn the anti-Hussite agitation using St. Wenceslas and other Bohemian saints, Šmahel, Idea národa, 53.

${ }^{97}$ Halama, "Utrakvistická úcta k českým světcům," 191.

98 St. Wenceslaus is depicted eg. in the graduals of Kutná Hora (Kuttenberger Cantionale, Vienna, Österreichische Nationalbibliothek, Musiksammlung Mus. Hs. 15.501, fol. 108r, dated 1509-16), Žlutice (Graham, Bohemian Graduals, 501, cat. no. 111, 4r) and Prague Lesser Town (Prague, Národní knihovna, XVII A 3, pars prima, Graham, Bohemian Graduals, 367, cat.no. 70, 78v).

${ }^{99}$ His feast occurs 36 times in the Utraquist graduals, which is the highest number after the Virgin Mary, Hus, St. John the Baptist, St. Mary Magdalene, St. Peter and Paul, and St. Lawrence. Žůrek, Officia svatých v českých graduálech 16 . století. 
with the text of a radical Hussite song. ${ }^{100}$ He takes a prominent position on the Utraquist altarpieces, where he is joined by other Bohemian saints, St. Ludmila, St. Procopios, or St. Vitus, as on the altarpieces from Slavětín (c. 1450), Libiš (after 1500) and Litoměřice (c. 1540). ${ }^{101}$ Hus and Jeroným of Prague are depicted with St. Wenceslaus and St. Procopios on the altar predella from Chrudim, c. 1500: The altarpiece originating from a local funerary church of St. Cross shows the Resurrected Christ in the centre, and Mary with John the Baptist as intercessors (Deisis) in the extension, portraying the Bohemian saints as helpers at the Last Judgement.

Accentuating preaching and the active life of the faithful community, the Utraquists deniedto the meaning of secluded monastic life. ${ }^{102}$ Monasteries were targeted in the Hussite wars. They were largely destroyed or fell in decline and isolation, from which they were slowly recovering in the

100 MB (Milena Bartlová), "VI-9 Pavéza města Kutné Hory se sv. Václavem,” in Umění české reformace, 204.

${ }^{101}$ Pešina, Česká malba, 100, 115. Kateřina Horníčková, "V-23, Oltář sv. Jakuba Většího z Libiše,” in Uměni české reformace, 153. Otakar Votoček, Severočeská Galerie Výtvarného Uměni v Litoměřich - sbírka starého umění: stručný prưvodce a katalog vystavených děl (Litoměřice: Galerie výtvarného umění Litoměřice 1983), unpag.

102 Jaroslav Kadlec, Svatý Prokop (Rome: Křest’anská akademie 1968), 101. 
course of the 16th century. In spite of the negative attitude to the ideas of monasticism that led to neglecting monastic saints, St. Procopios of Sázava enjoyed popularity among the Utraquists. ${ }^{103}$ Homilies on the feast of St. Procopios are preserved from Hus and other Hussite preachers. Rokycana, who was once accused of not keeping his and other patron saints' feasts, and of denouncing pilgrimages to his tomb, ${ }^{104}$ held homilies to his feastday, where he praised his moral and pure life. ${ }^{105}$ Echoing this, another $15^{\text {th }}$ century Utraquist homily to St. Procopios' feast invokes his purity, and victory over devil, ${ }^{106}$ but warnsagainst pilgrimages to his tomb, and

103 Žůrek, Officia svatých v českých graduálech 16. století. Procopios’ feast occurs in 24 graduals.

104 Šimek, ed., Postilla Jana Rokycany, vol. 2, 396, Kadlec, Svatý Prokop, 106.

105 Kadlec, Svatý Prokop, 102, with reference to Johannes Rokycana, Sermones de tempore et de sanctis, quadragesimale super evangelia et epistolas, Ms. NK IX A 1, fol. 222r. The sermon on purity is introduced with In die Procopii (note well Procopius is not called saint here).

106 "Feasts of saints were introduced so that we could praise God due to their teaching and merits, as we are exhorted to it by David's saying: Praise God in his saints. And if we should praise God in foreign saints, the more we should praise God in our patrons, as God gave them to us from his special grace, and they before others were beneficial to us and interceded on behalf of us in heaven. Today we celebrate St. Procopios...who prays constantly for his people, and we should thank God for such a defender and intercessor for this country. And should he help us with his prayers and merits, we should cease to sin, imitate him in purity, and throw out of us deamons of sins as he did, shine to them as a torch with good deeds. Imitating virtuous life of Procopios will be more profitable for us than running to him (to his relics in Sázava). And how 
against relics. Kadlec explains his popularity by events from his legend - exorcisms of the devil, and his leading a pure life, as well as his expression of anti-German sentiments; ${ }^{107}$ in the latter, he sees also the reason for the decline of the cult after the lutheranisation of Utraquism.

With a comparable number of occurrences of feasts in the Utraquist graduals, ${ }^{108}$ two other Bohemian patron saints, St. Ludmila and St. Vitus, enjoyed similar popularity as St. Procopios. St. Ludmila's legend was understood by the Utraquists as a justification of lay chalice, as she was thought to have communicated from a chalice on the eve of her martyrdom. ${ }^{109}$ In the monumental painting, she is coupled

pure he was and how his life shone to heaven for others, we read his message: Let your loins be girded about, and your lights burning;...no pilgrimage nor bones of saints will save you, whatever you do if you will not keep all the mandates of Christ. This is the way to eternal life.” Prague, Národní Muzeum, Ms. XIV E 9, Procopii festa sanctorum ideo indstituta sunt, ut laudemus Deumex eorum doctrina et profectu, fol. 107r - 111, cited in Kadlec, Svatý Prokop, 102-3.

${ }^{107}$ If this included also his reported support for Slavonic liturgy remains to be clarified, but is supported by the fact that the Utraquist also revived the cult of the Moravian/Slavic apostels St. Konstantin and Methodius, whose feasts appear in the Utraquist graduals as well, cf. gradual of Franus, Hradec Králové, Muzeum východních Čech, Hr 6, II A 6, B1, ft. 83.

108 Žůrek, Officia svatých v českých graduálech 16. století, found in 24 and 22 graduals.

109 Šimek, Postilla Jana Rokycany, 777, and Bohuslav Bílejovský, Kronyka Cýrkewnj, w njž se přjběhowé a přjhody cýrkwe České od gegjho počátku až do léta Paně 1532 wyprawugj (Prague: Vetterl z Wildenbrunu, 1816), 2. To this, see also the polemical reaction by the Catholic administrator Hilarius of Litoměrice in his treatise on communion sub una 
with St. Wenceslas, such as in the mentioned life-size representations on the outside wings of the angelic tabernacle altarpiece with Passion scenes from Libiš (Mělník District), c. $1500 .{ }^{110}$ The feast of St. Vitus occurs mostly in the graduals from Central Bohemia. He is depicted with St. Wenceslas on the altarpiece from Litoměřice, dated c. $1540 .^{111}$

Not all Bohemian patron saints reached the same level of popularity. St. Adalbert feast we find rarely in the graduals, ${ }^{112}$ and similarly in visual representations. This suggests that St. Adalbert constituted an ambiguous figure for the Utraquists, possibly due to his association with the Prague See and Rome. A revival of his cult came in the 16th century, when his feast was reintroduced in the Utraquist hymnals. The reasons for this development need further investigation, but it could have been the result of a complicated religious situation, when the conservative Utraquists tried to counter the Lutheran and Unitarian influence by insisting on the ancient roots of the Bohemian (Utraquist) church, a proper episcopal lineage, transubstantiation, and lay chalice - all that St. Adalbert

specie, quoted in Halama, "Utrakvistická úcta k českým světcům," 190, ft. 5.

110 Pešina, Česká malba, 115. Kateřina Horníčková, "V-23, Oltář sv. Jakuba Většího z Libiše," in Uméni české reformace, 153. Cf. ft. 97.

${ }^{111}$ Votoček, Severočeská Galerie Výtvarného Uměni v Litoměřich, unpag.

${ }^{112}$ Found in 9 graduals. Žůrek, Officia svatých v českých graduálech 16. století. 
symbolised in one. The last three notions are manifested on the panel from the dismantled Vliněves altarpiece, where St. Adalbert is serving mass from a chalice, whilst Hus holds his chasuble, whose decoration with a living body of Christ is an argument against Unitarian remanentism. ${ }^{113}$

Probably due to the negative impression the Emperor Sigismund of Luxembourg left in Bohemia, ${ }^{114}$ the cult of St. Sigismund, a miracle working cult heavily promoted in Prague by the Emperor Charles IV since the body's translation in 1365, almost disappeared from the Utraquist calendar. Only four graduals contain his feasts, and these date to the early decades of Utraquism. ${ }^{115}$

\section{Saints as Symbols of Utraquist Identity}

\footnotetext{
${ }^{113}$ Kateřina Horníčková, "V-19 Deska z oltáře z Vliněvsi se sv. Vojtěchem a Janem Husem," in Uméní české reformace, 142-4. Jan Royt - Jiří Fajt, "Sv. Vojtěch s Mistrem Janem Husem," in Svatý Vojtěch. Tisic let svatovojtěšské tradice v Čechách (Prague: Národní galerie, 1997), 108-9, cat. 54.

${ }^{114}$ David Mengel, "Remembering Bohemia's Forgotten Patron Saint," Bohemian Reformation and Religious Practice 6 (Prague: Academy of Sciences of the Czech Republic, Main Library, 2007), 19-20.

${ }^{115}$ Žůrek, Officia svatých v českých graduálech 16 . století.
} 
Whilst largely lacking traditional hagiographic media as legendaries, martyrologies or devotional literature, ${ }^{116}$ scholars of the 15th century Bohemia have a unique opportunity to study the symbolic communication through saints in a society divided along denominational lines disputing over the traditional medieval cult of saints. The more the Utraquists doubted external cult expressions and the intercession of saints, the more they turned to the other important functions and potential of the saints, needed for communication, internal evangelisation and confessionalisation of the heterogeneous religious community. On one hand, the importance of symbolic functions grew - the saints served as exempla, reminders of the ideal past and shared symbols of Utraquist denominational identity. On the other hand, the Hussite critique and Utraquist scepticism transformed the Utraquist understanding of the role of saints in the cults, and the practices of their veneration. The cult of saints never returned to its pre-Hussite meaning and form.

One of the many functions of saints in the late Middle Ages is to form religious communities around the symbolic value of saints. The Bohemian Utraquist church esteemed

\footnotetext{
116 They are rare among the Bohemian materials: among them are hagiographic collections Vitae patrum, and the already-mentioned Bohemian Pasional.
} 
chosen saints for their moral reputation and steadiness in faith and did not need episcopal affirmation to their cults. ${ }^{117}$ It framed its identity as a religious community first through fostering its own martyr cults, and, secondly, by choosing appropriate cults that exemplify the role the saints should perform in Utraquism. The new Bohemian martyr cults helped to construct autonomy and an independent identity of Utraquism. The early Church martyrs provided an ideal model of society, morals and religious practice, and the Bohemian patrons supported local attachment, tradition, morals and the lay chalice.

The Utraquists gave a special meaning to the new, modern saints living among the faithful, emulating the ancient ones. By stressing honouring by imitation they made the first step towards a modern concept of living saints, known also from Luther. From the long-established saints they particularly honoured the apostles and early Christian martyrs through their identification with ecclesia primitiva, the imitation of which legitimised the Bohemians as chosen Christians. They also appropriated a selection of the Bohemian patron saints to stress Bohemia's own way to Christianity and the autonomous origins of the Bohemian Church. This envisioned the

${ }^{117}$ Woodward, Making Saints, 62-5. 
Utraquists as authentic inheritors of a rich religious past, in which they seeked the justification of their own religious practice of the lay chalice (St. Ludmila, St. Adalbert). With the exception of relics and pilgrimages, traditional religious media were adopted for the new Bohemian Reformation martyr cults (Jan Hus, Jeroným). Hus was linked with the early Christian martyrs and his specific contexts, constituting him as the martyr founder of a new faith. The cults of St. Jan Hus and Jeroným of Prague denoting Utraquism as an independent religious community gave a new spark to the meaning of saints. Prior to the Reformation, it brought a new type of saint, the founder and defender of faith without miracles and a vita. Such a saint, challenging the authority of the Roman Church, would become a saint without papal consent, only by imitation of the ancient Church, a martyrtranscending the past and bringing the apostolic time alive in the present. On the other hand, the Utraquist theological Christocentrism pushed saints aside to assistant roles, to the wings and predellas of altarpieces and to the margins of graduals. The Utraquists kept them as authority on how to lead a proper Christian life, transforming their role in the cult and limiting their cultic function. Some cults were marginalised, such as those of bishops and monastic saints, 
the traditional symbols of the Church, papal authority, and the doctrine. ${ }^{118}$

By creating their own saints and appropriating others, the Bohemian Reformation had created an amalgam of cultural memory and religious tradition to serve the idea of an autonomous alternative to the Roman Church. Seen by many as traditionalists for keeping the pre-Hussite calendar and cultic practices beyond the Tridentinum, the Utraquists contributed considerably to the transformation of the late medieval cult of saints. Although the changes may seem minor in comparison to those brought by the German Reformation, their re-definition of the cult of saints is coherent with the effort to conceptualise the Bohemian church as a separate entity within Latin Christianity.

\footnotetext{
${ }^{118}$ Parish patron and locally important saints have not been touched by this. Some saints, such as St. Nicholas, enjoyed popularity throughout the period as patrons of parish churches. The feast of St. Elisabeth in the gradual of Franus (Hradec Králové, Museum východních Čech, $\mathrm{Hr}$ 6) reflects her local importance in a dowry town Hradec Králové, as patron of royal female commissioners.
} 